\title{
Learning to Learn with Virtual Microscopes
}

\author{
Diana Jonas-Dwyer \\ University of Western Australia, \\ Perth, WA, Australia
}

diana.jonas-dwyer@uwa.edu.au

\author{
Fay Sudweeks, Tanya McGill, \\ and Philip Nicholls \\ Murdoch University, \\ Perth, WA, Australia
}

\author{
f.sudweeks@murdoch.edu.au, \\ t.mcgill@murdoch.edu.au, \\ p.nicholls@murdoch.edu.au
}

\begin{abstract}
Recent research (Jonas-Dwyer \& Sudweeks, 2007) indicated that when virtual microscopes were introduced to third year health science students as part of their histology and pathology laboratory work, no detrimental effects were found. To investigate the use of virtual microscopes further, an extended study was undertaken with both second and third year health sciences students. In this paper, we report the results of students' learning approaches and compare the outcomes to identify and evaluate changes in students' learning approaches when using virtual microscopes rather than optical microscopes.
\end{abstract}

Keywords: learning, learning approaches, virtual microscopes

\section{Introduction}

Research into student learning (e.g., Biggs, 2003; Mccune \& Entwistle, 2000) has found that learning is influenced by factors such as individual student characteristics, the learning environment, and teachers' teaching styles. Some student characteristics (e.g., cognitive styles) are considered to be 'fixed', whilst other characteristics (e.g., students' learning approaches) are considered to be more 'adaptable'. The approach that is most often encouraged at a tertiary level is that of a deep approach, where focus of the students is on understanding the subject. A surface approach is discouraged, as it is characterized by memorization of facts and is often motivated by a fear of failure.

How students' learning approaches are influenced by using technology is not clear. Weigel (2002, p.5) states that "[f]rom a practical standpoint, deep learning and e-learning are inseparable" but Russell (1999) reported no significant difference between students learning by distance with technology and students learning by traditional methods.

Material published as part of this publication, either on-line or in print, is copyrighted by the Informing Science Institute. Permission to make digital or paper copy of part or all of these works for personal or classroom use is granted without fee provided that the copies are not made or distributed for profit or commercial advantage AND that copies 1) bear this notice in full and 2) give the full citation on the first page. It is permissible to abstract these works so long as credit is given. To copy in all other cases or to republish or to post on a server or to redistribute to lists requires specific permission and payment of a fee. Contact Publisher@InformingScience.org to request redistribution permission.
One of the traditional tools used to teach health science students about histology and pathology is the optical microscope. However, Farah and Maybury (2009) say that students find them difficult, frustrating and tiresome. Students complain about the quality and consistency of use, which has a detrimental effect on their engagement with the course content. With the advent 
of newer technologies, virtual microscopes are now being introduced and there are signs that, in the near future, diagnostic pathology will be transformed with virtual microscopy (Scott, 2008).

A virtual microscope is hardware that allows users to zoom and change magnification (e.g., 20x to 40x) to examine digitized slides. Virtual microscopes are different from electronic simulations of a microscope; the virtual microscope's components can be manipulated, e.g. slides, light aperture, and focus.

Although virtual microscopes were first developed to accommodate physically disabled students (Pritchard, 1996), it quickly became apparent that they were also suitable for students studying remotely. Technological advances meant that virtual microscopes were continually developed and refined and that, by the early 2000 s, their potential as a valuable tool was recognized by pathologists (Demichelis, Barbareschi, Dalla Palma, \& Forti, 2002; Leong \& Mcgee, 2001). At the same time, virtual microscopes were introduced to undergraduate medical teaching (Harris, Leaven, Heidger, Kreiter, Duncan, \& Dick, 2001).

In educational institutions, there are increasing pressures on academics to incorporate economically efficient, as well as effective means to teach their subject specialties. The increased use of technologies, prima facie, appears to be the solution. Jonassen, Peck and Wilson (1999, p. 218) say that "Technologies ... should be used as tools that students learn with ... When students learn by using technologies as tools for growing and sharing ... they are learning meaningfully".

The introduction of virtual microscopes into the histology and pathology teaching and learning environment in an Australian university provided an opportunity for research into the effect of this technology on students' learning approaches, their learning and the affordances offered by virtual microscopes. Virtual microscopes have the capacity to create a technical barrier or provide greater flexibility of delivery, including remote learning. This study extends previous research (Jonas-Dwyer \& Sudweeks, 2007) that found no detrimental effects on the learning of a small sample of third year undergraduate health sciences students after the introduction of virtual microscopes. Using a larger sample of both second and third year undergraduate students, this study compared students' learning approaches when using optical or virtual microscopes as part of their histology and pathology laboratory work and analyzed students' reflections on their learning activities.

\section{Methodology}

The study used a mixed methodology containing both quantitative and qualitative components. The mixed methods approach was applied to an embedded case study design to evaluate the intervention of virtual microscopes and to determine any change to students' learning approaches. Mixed methods allow for more diverse perspectives to be examined (Creswell \& Plano Clark, 2007). Case studies can be used "to describe an intervention and the real life context in which it occurred" (Yin, 2003, p.15). Embedded cases involve more than one unit of analysis, contain subunits that focus on different aspects of the case, and are not restricted to using only qualitative methods (Scholz \& Tietje, 2002).

The potential participants were 348 students studying second year Biomedical Sciences (BMS264), second year Veterinary Science (VET244) or third year Chiropractic (CHI301). Data for the study was collected at various times during a 13 week teaching period. Prior to the students' first laboratory class, a member of the teaching staff randomly allocated each student to either a virtual or optical microscope laboratory class.

In their first laboratory class, students attended a presentation by the researcher explaining the study and describing what being a participant in the study entailed. Students had two (CHI301) or three (BMS264, VET244) hours of microscopy activities per week, over 12 (CHI301) or 4 
(BMS264, VET244) sessions. The optical microscopy classes were based around six 10-header Olympus microscopes (Figure 1). A group of students work together on each 10-header microscope. A demonstrator's video-microscope relays to four wall-mounted monitors.

The virtual microscopy microscopes were based around 20 laptops (Figure 2). Each computer had the Aperio ${ }^{\mathrm{TM}}$ viewer software (ImageScope). The software allowed students to see a thumbnail of a virtual slide as well as to zoom in on particular parts of the slide. The software also contained several handy tools, e.g. allowing exact coordinates to be seen for the section of slide that the student is focused on, a ruler to measure a section of slide, a camera that allowed students to take a snapshot of a particular section of a slide, and an annotator that can be used to annotate sections of the slide. Normally two students sat together to use the virtual microscope. A demonstrator moved around the room, as in the optical laboratory groups' class. To address the class as a whole, the demonstrator had a virtual microscope projected onto a larger screen via a data projector.

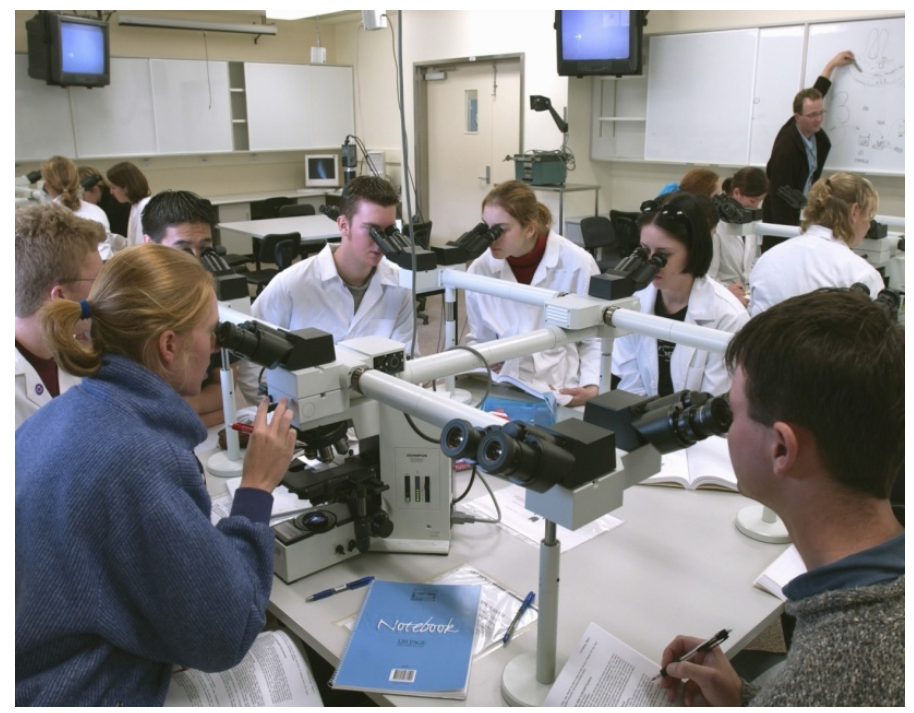

Figure 1. The optical microscope laboratory set-up

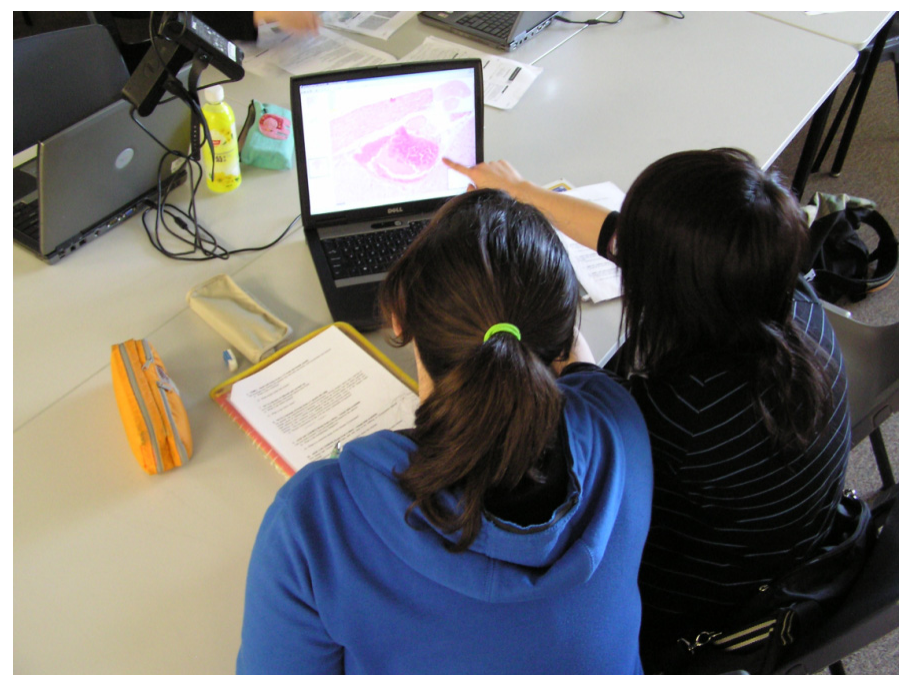

Figure 2. The virtual microscope laboratory set-up 
Assessment in these units included theory questions as well as visual recognition and interpretation tasks relating the work covered in the microscopy laboratories.

There were three instruments for the study. The Approaches and Study Skills Inventory for Students (ASSIST) (Tait, Entwistle, \& McCune, 1998) was completed by students at the beginning and the end of the teaching period. Students also responded to a brief demographic survey, and recorded reflections on their activities with microscopes.

\section{Results}

\section{Demographics}

For the demographics survey, 293 responded and their responses were analyzed. There were 269 students who submitted reflections. Only 151 students submitted both ASSIST surveys. Of the 151 students, 81 were in the Optical Group and 70 were in the Virtual Group. The demographic survey collected background information on the students, including gender, age, ICT experience and perceived use of microscopes in their career.

There were more females than males who participated in the study (Figure 3). This predominance of females was representative of the gender split of the entire group.

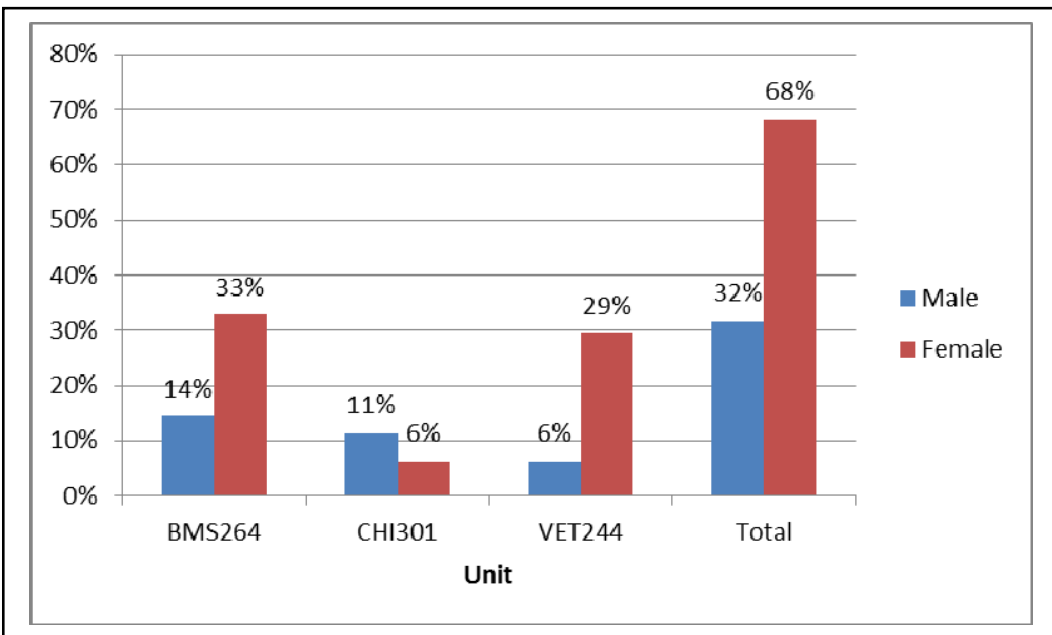

Figure 3. Gender by unit

The age range of the two groups was between 18 and 46 years with the majority of students falling into the $<=19$ and 20-24 year age groups (Table 1). The groups were almost equal in number and had a similar proportion of students in the 19-29 age groups. The Optical Group had slightly more mature students (30-40+) than the Virtual Group.

Students rated their skills using the Internet and computers on a scale of 1 (very skilled) to 5 (little or no skills). Figure 4 shows that the majority of the students in both groups rated themselves as possessing above average levels of skills and almost a third rated themselves as having average skills. A small proportion of students rated themselves as having little or no skills. The proportion of students identifying with each level of skill was roughly the same, regardless of laboratory group allocation. 


\begin{tabular}{|l|r|r|r|r|}
\hline \multicolumn{5}{|c|}{ Table 1: Age range of students by laboratory group } \\
\hline \multicolumn{1}{|c|}{$\begin{array}{c}\text { OPTICAL (\%) } \\
\text { NGE }\end{array}$} & $\begin{array}{c}\text { VIRTUAL(\%) } \\
\text { N=137 }\end{array}$ & $\begin{array}{c}\text { TOTAL (\%) } \\
\text { N=293 }\end{array}$ \\
\hline$<=19$ & 20 & 18 & 38 \\
\hline $20-24$ & 22 & 20 & 42 \\
\hline $25-29$ & 5 & 6 & 11 \\
\hline $30-34$ & 3 & 1 & 4 \\
\hline $35-39$ & 2 & 1 & 2 \\
\hline$=>40$ & 1 & 1 & 2 \\
\hline
\end{tabular}

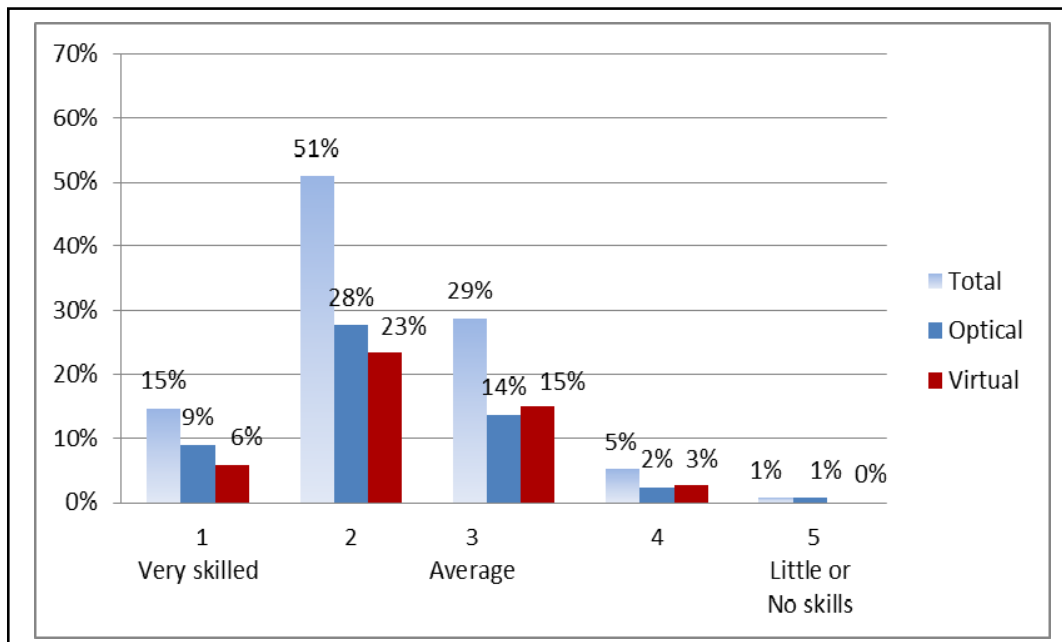

Figure 4. Students self-rating of ICT skills by group $(n=293)$

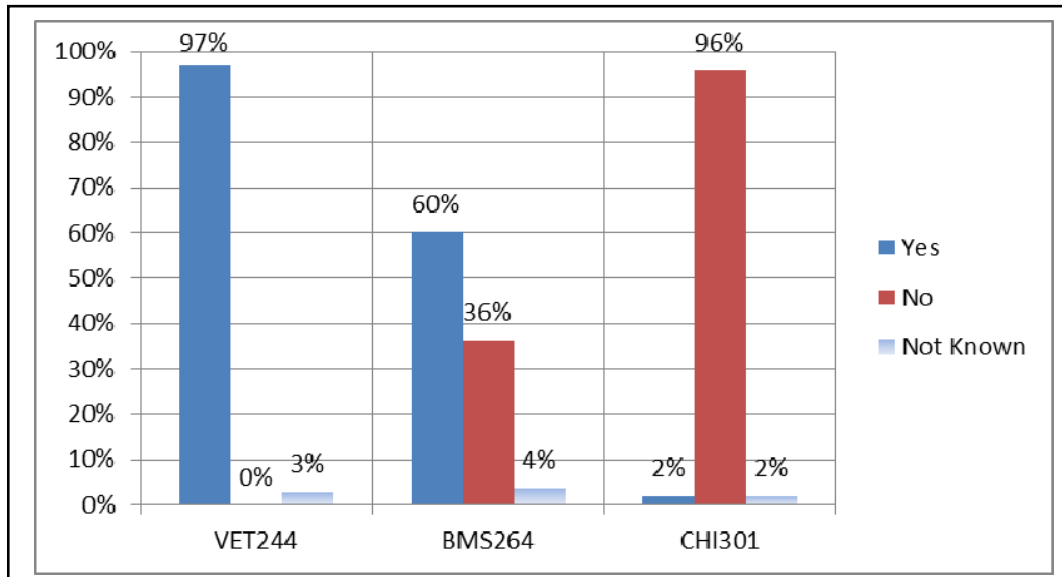

Figure 5. Students identifying potential microscope use in their career by unit

Students were asked to identify whether they expected to use a microscope in their career and approximately two thirds said that they did. As chiropractors are less likely to use microscopes in their career than veterinarians or biomedical scientists, further analysis was required on the unit category. Figure 5 illustrates the unit breakdown. The majority of veterinary science and biomedical sciences students (97\%) responded positively to this question. 


\section{The ASSIST survey}

The ASSIST has been demonstrated to be a reliable measure of learning approaches in a number of studies (e.g. Entwistle, Tait, \& McCune, 2000; Speth, Namuth, \& Lee, 2007: Tait, Entwistle, \& McCune, 1998) as well as being an instrument that is contextually relevant to higher education (Coffield, Moseley, Hall, \& Ecclestone, 2004). The ASSIST instrument contains three distinct sections. Section A determines students' current conceptions of learning. Section B of the ASSIST identifies students' individual approaches to learning: deep, strategic or surface. Section C identifies students' preference for different types of course and teaching. In this paper, we report the results for Section B only to evaluate students' learning approaches in considering the affordances of virtual microscopes.

At the beginning of semester (ASSIST1), more Optical Group students identified a deep approach to learning than strategic (Table 2). The largest proportion of students (39\%) identified a surface approach to their learning. At the end of semester (ASSIST2), the number of students identifying a deep approach to learning remained the same. There was a slight increase in the strategic approach, and surface approach decreased slightly. These results indicate that there was little change in the approaches to learning of the Optical Group during the teaching period.

Table 2. Approaches to learning for the Optical Group

\begin{tabular}{|l|r|r|r|r|}
\hline SURVEY & \multicolumn{3}{|c|}{ LEARNING APPROACH } & TOTAL (\%) \\
\hline ASSIST1 & Deep (\%) & Strategic (\%) & Surface (\%) & \\
\hline ASSIST2 & 32 & 28 & 39 & 100 \\
\hline
\end{tabular}

In Figure 6 (a-c), each learning approach is grouped by unit. Even though some VET244 students in the Optical Group moved from a deep approach to either a surface or strategic approach, overall there was no change in the overall proportion of students using a deep approach during the teaching period. However, there was a slight increase in the proportion of students using a strategic approach and decrease in the number of students using a surface approach.

Table 3 shows the results for the Virtual Group. At the beginning of semester (ASSIST1), the greatest proportion of students identified a surface approach to their learning. Fewer students identified a deep approach or strategic approach. At the end of semester (ASSIST2), the number of students identifying a deep approach to learning had decreased slightly and there was a very small decrease in strategic with a larger increase in surface. The number of students identifying either a deep or strategic approach decreased slightly while there was a small increase in surface approach.

Figure 7(a-b) shows Optical Group students' approaches to learning by unit. In BMS264 there was a move from both deep and surface approaches to strategic. In VET244 there was large shift from strategic to either deep or surface approaches. This could be due to some students trying to understand the subject and others focusing on just passing the unit. In CHI301 there was a small change from deep to strategic approach.

Table 4 shows that, in the Optical Group, a small proportion moved away from a surface approach to a strategic approach, whereas in the Virtual Group, a small proportion moved away from deep and strategic approaches to a surface approach. This result was explored further using the chi-squared test of independence. A chi-square test of independence indicated no significant association between group and learning approach, $\chi^{2}(2, \mathrm{n}=151)=1.143, \mathrm{p}=0.56$ or between units and learning approach, $\chi^{2}(4, \mathrm{n}=151)=8.028, \mathrm{p}=0.91$. 


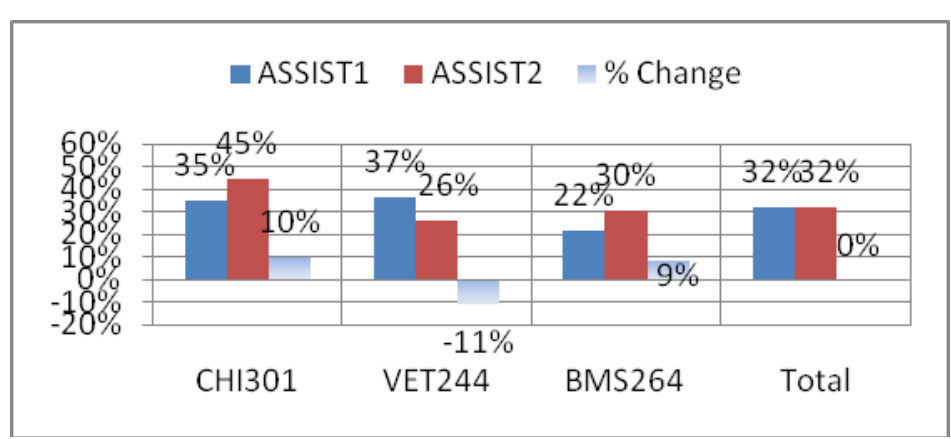

(a) Deep approach

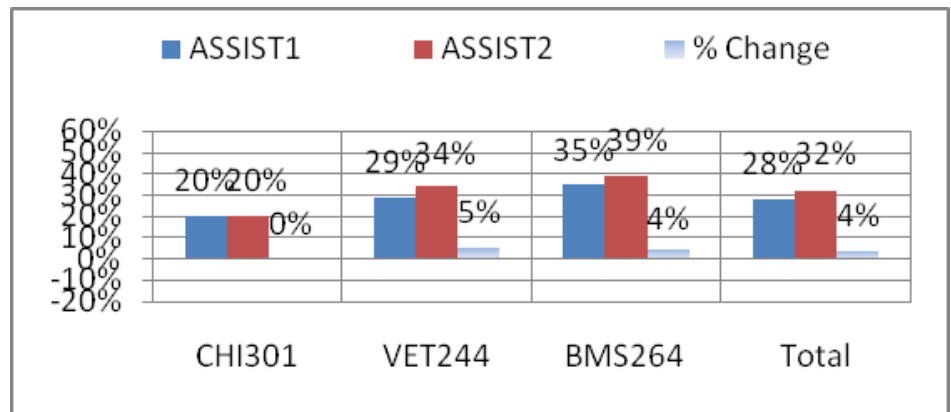

(b) Strategic approach

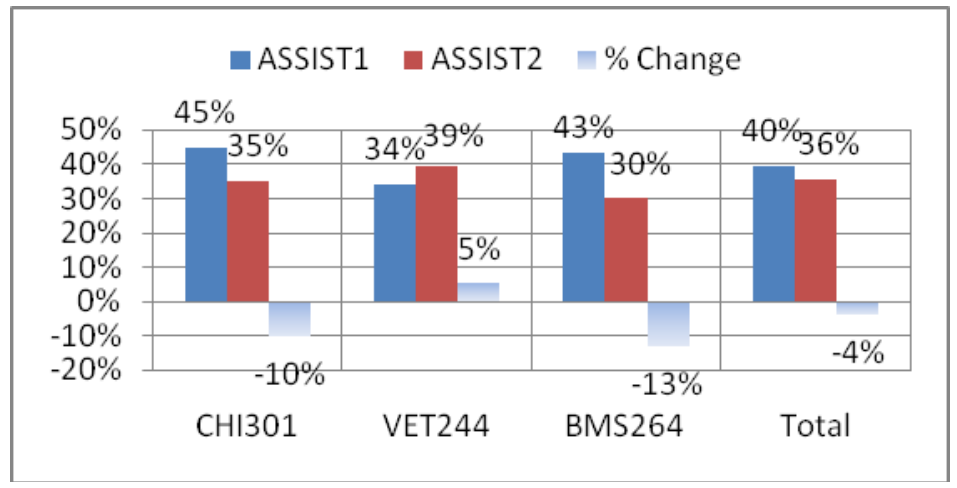

(c) Surface approach

Figure 6. Optical Group students' learning approaches by unit

Table 3. Approaches to learning for the Virtual Group

\begin{tabular}{|c|r|r|r|r|}
\hline & \multicolumn{3}{|c|}{ LEARNING APPROACH } & \\
\hline Survey & Deep (\%) & Strategic (\%) & Surface (\%) & Total (\%) \\
\hline ASSIST1 & 30 & 31 & 39 & 100 \\
\hline ASSIST2 & 27 & 29 & 44 & 100 \\
\hline
\end{tabular}




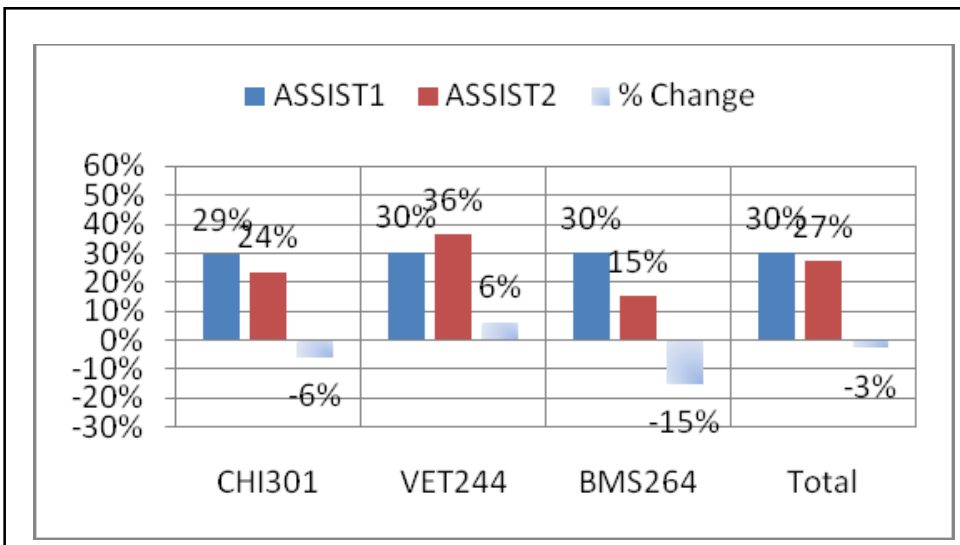

(a) Deep approach

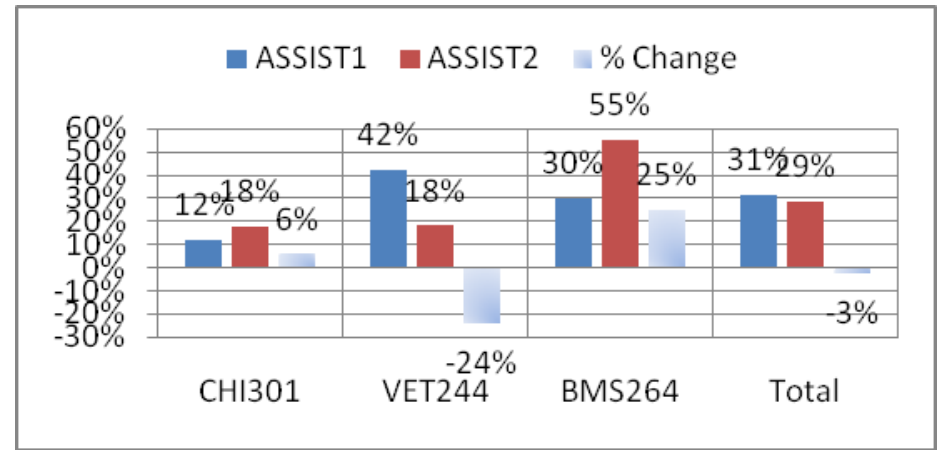

(b) Strategic approach

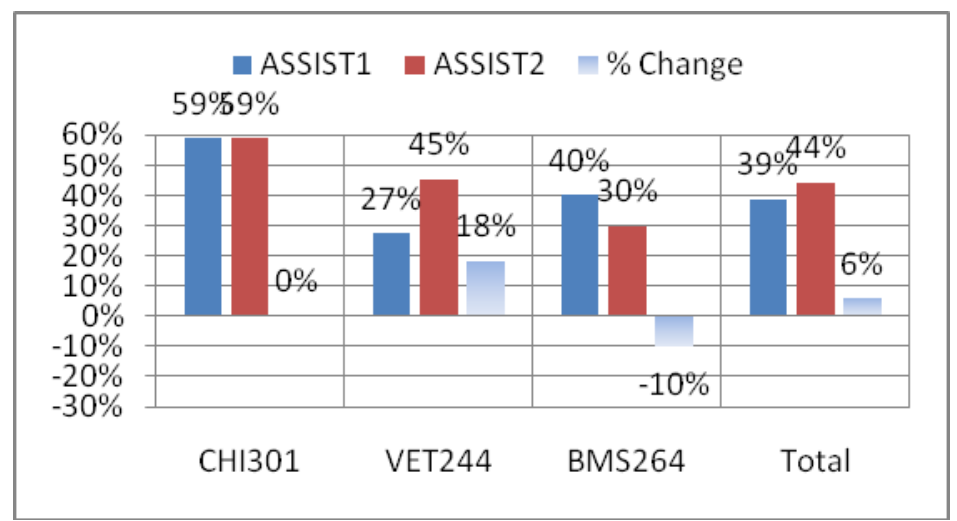

(c) Surface approach

Figure 7. Virtual Group students' learning approach by unit

Table 4. Changes to learning approaches over the teaching period

\begin{tabular}{|c|c|c|c|}
\hline & \multicolumn{3}{|c|}{ Learning Approach } \\
\hline Group & Deep (\%) & Strategic (\%) & Surface (\%) \\
\hline Optical & 0 & +4 & -4 \\
\hline Virtual & -3 & -3 & +6 \\
\hline
\end{tabular}


In summary, although there were a small proportion of students who changed their learning approaches during the teaching period, the changes were not significant.

\section{Reflections on Activities}

In addition to the ASSIST and demographic surveys, students were asked to reflect on their activities with microscopes. The question eliciting their responses was "describe how the activities with microscopes helped your understanding of the course materials". The open-ended question was content analyzed and twelve themes emerged. The themes are listed in Table 5.The six most frequent themes are described and illustrated with quotes from students (reproduced verbatim), which are coded to identify group, gender and identity (e.g. $\mathrm{O}=$ optical, $\mathrm{V}=$ virtual; $\mathrm{M}=$ male, $\mathrm{F}=$ female, Identity=1-269). The other six themes were mentioned by only a few students so they are described briefly.

Table 5. Themes in student reflections on microscope activities

\begin{tabular}{|c|c|c|c|c|}
\hline \multicolumn{2}{|c|}{ ACTIVITY THEMES } & $\begin{array}{c}\text { OPTICAL (\%) } \\
\text { N=146 }\end{array}$ & $\begin{array}{l}\text { VIRTUAL (\%) } \\
\qquad \mathbf{N}=123\end{array}$ & $\begin{array}{l}\text { TOTAL }(\%) \\
\text { N=269 }\end{array}$ \\
\hline 1 & Linking theory with practice & 36 & 34 & 35 \\
\hline 2 & Visualising & 17 & 22 & 19 \\
\hline 3 & Authenticity & 12 & 15 & 13 \\
\hline 4 & Group discussion & 12 & 2 & 7 \\
\hline 5 & Revision & 5 & 7 & 6 \\
\hline 6 & $\begin{array}{l}\text { Building skills in tissue } \\
\text { identification }\end{array}$ & 5 & 5 & 5 \\
\hline 7 & Teacher guidance & 3 & 4 & 3 \\
\hline 8 & Engagement & 1 & 3 & 2 \\
\hline 9 & Convenience & 0 & 4 & 2 \\
\hline 10 & Time management & 0 & 4 & 2 \\
\hline 11 & Focus & 0 & 2 & 1 \\
\hline 12 & Developing microscope skills & 0 & 1 & 0 \\
\hline
\end{tabular}

\section{Theme 1: Linking theory with practice}

Nearly equal numbers of students from both laboratory groups $($ Optical $=36$; Virtual $=34)$ thought that the activities with microscopes helped to link the theory of histology and pathology with practice. This is not surprising given that histology and pathology are visual sciences.

In the Optical Group, students said that, by seeing how the tissue structures enabled functions to occur in organs, it made the lectures come to life and assisted their understanding of histology and pathology.

It made the lectures come to life in a sense. It made it easier to absorb when you see first hand what they are talking about [OF08].

Understanding the structure made it easier to understand function [OM125].

I was able to understand how the structures of the tissues enable certain functions to occur in the organs [OF120].

relates the lecture materials to actual slides [OF127]. 
The Virtual Group students also said that activities helped them to learn better by providing a link to what the lecturer taught and helped to make things make more sense.

could see it at a cellular level and could really understand why it is structured to function optimally, it was really useful to have the microscopes!!! [VF281].

Taking theoretical information and applying it, stimulating different thoughts and helping to learn better, getting a feeling of a more rounded understanding through the practical element [VM274].

Provided a link to what [the lecturer] lectured about and what we read in text books [VM290].

it increased my understanding of the different tissues in the body and how those differences (on a cellular level) allow them to function within the body and to maintain homeostasis. it just seemed to make things make more sense! [VF277].

\section{Theme 2: Visualising}

Students from both groups found that the microscope activities helped them to visualize concepts and to remember images (Optical = 17; Virtual =22). The Optical Group also found the activities made it easier for them to remember concepts and images at exam time, while the Virtual Groups' comments reinforce the importance of visualizing what is learned. In other words, the students appear to be creating mental maps of what they learn.

The comments from the Optical Group students illustrate the helpfulness of the activities in developing their visualization skills.

Being able to visualise what we discussed was extremely helpful and surprisingly the images were easy to remember [OF115].

It helped understand and visualise many concepts [OF74].

The miscroscopes were useful in helping me visualise a concept or description taught in lectures and it also makes it easier to remember come exam time. Also trying to find the characteristics of tissues on micropscope slides myself allowed me to test my understanding and helped me realise what $\mathrm{i}$ already knew and what i may have needed to work on [OF066].

It was easier to visualise the material covered in the histology lectures. It helped my understanding of structures of organs and I was able to retain information about the structures more easier [OF073].

The Virtual Group found the activities helped them to visualize what it was they were actually learning and with remembering some of the characteristics of the organs.

It helps in remembering the features/characteristics of the various organs [VF192]. gave a visual idea of how the specimens looked and how the structures of them looked also [VF213].

Allows you to visualise what it actually is that you were learning about. Allows for revision [VM316].

to better visualise the structures other than looking at a textbook. helped clarify their form [VF288]. 


\section{Theme 3: Authenticity}

Students from both groups thought the microscope activities were authentic (Optical=12; Virtual 15). Authentic activities are ones that have real life application and are often featured in constructivist learning environments.

It is interesting to note that the Optical Group students found the activities to be real, while the Virtual Group students found it helped them to see how things work at a cellular level, rather than it just being a bunch of slides. The Optical Group students' comments show that using the optical microscope was perceived to be authentic.

looking at something on a slide is much different from looking at it in a book. the whole process of using a microscope made whatever i was looking at so much more real instead of just a picture [OF62].

In class when we saw pictures of magnified material it was hard to imagine it in real life. When using the microscope you can look at the slide first with your naked eye and then zoom in progressively to see the detail and put it into perspective [OF140].

The Virtual Group students' also found the virtual microscope to be authentic.

The course material is just a banch of slides when working on microscope gives us the opportunity to realize how things work [VM199].

It showed what is going on at the cellular level so it was possible to see all the changes that inflammation had in detail and not just read about it in a book, you could actually see it going on. Especially with neoplasia that is something that I had such a different idea about and then i got to see it down the micropscope it made it so much more relevant. I think it was really valuable I never missed a lab [VF011].

\section{Theme 4: Group discussion}

Although both groups identified group discussion as one of the things that assisted them to understand the course material, more Optical Group students (12) identified this issue than the Virtual Group (2). This could be due to the physical structure of the optical laboratory, with one student driving the optical microscope and seven other students following. The opportunity for group discussion could be greater than in the Virtual Group where the laboratory is set up for 2-3 students per microscope.

Several comments from the Optical Group show how students worked together and discussed the activities in their groups:

Discussing things in a group and feeding off each others ideas, answering each others questions. Looking at the slides rather than just pictures from a book helped, seeing what the nerves actually looked like. Putting things into practice. [OF124].

Evryone in the group would pick out something they saw and we would discuss what it is, what it does and what structures could possibly be around it [OF094].

the co-operation of everyone and group learning, friends helping each other out and learning by teaching peers [OF056].

The following comment is representative of the comments from a few Virtual Group students. They appreciated the opportunity of collaborative work, illustrating the benefits of social constructivism.

We able to explore the whole slide instead of just being given a section picture of it in lectures. Working in a group was excellent, were able to utilize each others strenghts and 
could discuss the slides, allowing you to come to the correct conclusions and identify the right things [VM280].

\section{Theme 5: Revision}

Students from both the Optical Group (5) and Virtual Group (7) found that the activities helped them to revise the materials.

The Optical Group students mentioned various ways that the activities helped them, such as, being able to view slides from different perspectives and zooming into specific areas.

I found using the microscope was a good revision tool for me. It was a quick way to view all the tissues, and identify their specializations. It is also a good way to view the tissue as a whole, and then to zoom in on the areas that are of more interest to you. The lectures were good, but pictures on a page can be a little restrictive. The microscope was a good way to comprehend the 'big picture' of the tissue and its parts [OF070].

I used microscope as review material. On lecture power points, there is usually one part on one slide. It might have different shapes and looks on different occasion and specimen, so using microscope was useful to test myself to see if I can identify specific parts. Also by doing this, I can visualise how the part I am looking at associates with surrounding parts [OF185].

The Virtual Group students also mentioned the revision aspect of activities, though they were more general in their comments:

Tutorials were great, and easy revision meant I would look for something in a sample rather than just skim over it [VF224].

These microscoic activities were good revision, and gave me good expression how a particular structure looks like in real specimen [VF313].

\section{Theme 6: Building skills in tissue identification}

A small number of students in both groups (Optical $=5$; Virtual $=5)$ said that their skills in tissue identification were developed by doing the activities.

The Optical Group students were able to gain experience in identifying lesions and structures, as were the Virtual Group, who found that the activities helped to stimulate their memories and with histological identification.

gave me experience with identification of lesions [OM041].

The microscope activities helped me to identify structures. The study of tissues helped me to better understand gross or organ system physiology. The group environment allowed discussion of what the structures were, and their functions etc [OF183].

helped with tissue recognition and helped understand substances produced by certain cells in certain organs or tissues. It was like a memory stimulant for other areas [VF228].

it gave me more practice at identifying histological specimens [VF262].

\section{Themes 7-12}

A small group of students from each group felt that the activities were made meaningful due to the guidance they received from their teacher. In some cases, the teacher was a laboratory demonstrator, while in other cases, the teacher was the lecturer. In addition to helping with 
revisions, a few students thought that the activities with microscopes helped them to be more engaged in the material.

A few students from both groups identified the convenience of the virtual microscope as a contributing factor to their increased understanding. As access to the optical microscopes was restricted mainly to laboratory classes due to limited resources, there was a distinct advantage for the Virtual Group to be able to study at home in the middle of the night.

Some students in the Virtual Group commented that being able to focus the microscopes had assisted them with understanding the course material.

The last two themes identified by students using the virtual microscopes were time management and microscope skills. They felt they were able to be more flexible with their time and having to learn a new technology contributed toward their understanding of the material.

\section{Discussion and Conclusion}

The results of this study indicate that virtual microscopes can be integrated into health science learning without impacting on learning approaches or student perceptions of the positive role of microscopes in supporting their learning.

Whilst there were minor shifts in learning approach over the length of the study, these occurred in both the optical microscope group and the virtual microscope group, and no significant association between type of microscope used and learning approach was found.

In the main, use of virtual microscopes as opposed to optical microscopes did not appear to impact on students' perceptions of how microscopes contribute to their understanding of subject materials. The one aspect where differences were noted was that of group work. Students found the optical microscopes more congenial to group work. This relates to the environment in which the different kinds of microscopes were used. In the optical laboratory, the equipment was configured to have one student driving the optical microscope and seven other students following. The virtual microscope group had more flexibility to work individually or in smaller groupings.

Twelve activity themes were identified. Both groups had similar comments about the themes with the exception of group discussion. Students found the optical microscopes more congenial to group work. On the other hand, students using virtual microscopes commented on features such as engagement, convenience, time management, focus and skills. As virtual microscopes become more widely used, students will expect the flexibility and mobility that the virtual microscopes provide.

One area in which perceptions might have been expected to differ was that of authenticity. There did not however appear to be a difference in perceptions of authenticity of their tasks between the groups.

\section{References}

Biggs, J. (2003). Teaching for quality learning at university (2nd ed.). Berkshire, England: Open University Press.

Coffield, F., Moseley, D., Hall, E., \& Ecclestone, K. (2004). Learning styles and pedagogy in post-16 learning: A systematic and critical review. Wiltshire, England: The Learning and Skills Research Centre.

Creswell, J. W., \& Plano Clark, V. L. (2007). Designing and conducting mixed methods research. Thousand Oaks, CA: Sage Publications.

Demichelis, F., Barbareschi, M., Dalla Palma, P., \& Forti, S. (2002). The virtual case: A new method to completely digitize cytological and histological slides. Virchows Arch, 441, 159-164. 
Entwistle, N. J., Tait, H., \& McCune, V. (2000). Scoring key for the approaches and study skills inventory for students (ASSIST). Retrieved 25 August, 2005, from http://www.ed.ac.uk/etl/questionnaires/ASSIST.pdf

Farah, C. S., \& Maybury, T. (2009). Implementing digital technology to enhance student learning of pathology. European Journal of Dental Education, 13(3), 172-178.

Gibson, J. (1977). The theory of affordances. In R. Shaw \& J. Bransford (Eds,). Perceiving, acting, andknowing: Toward an ecological psychology (pp. 67-82). Hillsdale, NJ: Lawrence Erlbaum.

Harris, T., Leaven, T., Heidger, P., Kreiter, C., Duncan, J., \& Dick, F. (2001). Comparison of a virtual microscope laboratory to a regular microscope laboratory for teaching histology. The Anatomical Record (New Anat.), 265, 10-14.

Jacobson, M. J., \& Reimann, P. (Eds.). (2010).Designs for learning environments of the future: International perspectives from thelLearning sciences (1st ed.). New York, NY: Springer-Verlag.

Jonas-Dwyer, D., \& Sudweeks, F. (2007). Informing students using virtual microscopes and their impact on students' approach to learning. Informing Science: the International Journal of an Emerging Transdiscipline, 10, 61-70. Retrieved from http://www.inform.nu/Articles/Vol10/ISJv10p061070Dwyer395.pdf

Jonassen, D. H., Peck, K. L., \& Wilson, B. G. (1999). Learning with technology: A constructivist perspective. Upper Saddle River, NJ: Prentice Hall.

Leong, F. J. W-M., \& McGee, J. O. D. (2001). Automated complete slide digitization: A medium for simultaneous viewing by multiple pathologists. Journal of Pathology, 195, 508-514.

McCune, V., \& Entwistle, N. J. (2000). The deep approach to learning: Analytic abstraction and idiosyncratic development. Paper presented at the Innovations in Higher Education Conference, Helsinki, Finland, 30 August-2 September.

Pritchard, S. (1996). Wiring up the virtual campus. Retrieved 6 June, 2009, from http://www.independent.co.uk/news/business/wiring-up-the-virtual-campus-1341256.html

Russell, T. L. (1999). The no significant difference phenomenon. Raleigh, NC: North Carolina State University.

Scholz, R., W., \& Tietje, O. (2002). Embedded case study methods: Integrating quantitative and qualitative knowledge. London, England: Sage Publications.

Scott, T. (2008). Corporate news: GE venture to develop 'virtual microscope'. Wall Street Journal, p. B.5.

Speth, C. A., Lee, D. J., \& Hain, P. (2003). Get an ASSIST and support your students' learning online. Retrieved 11 July, 2009, from http://www.uwex.edu/disted/conference/Resource_library/handouts/03Info_H21.pdf

Tait, H., Entwistle, N., \& McCune, V. (1998). ASSIST: A re-conceptualization of the approaches to studying inventory. In E. Rust (Ed.), Improving students as learners (pp. 262-271). Oxford, England: Oxford Brookes University, The Oxford Center for Staff and Learning Development.

Weigel, V. B. (2002). Deep learning for a digital age: Technology's untapped potential to enrich higher education. San Francisco, CA: Jossey-Bass.

Yin, R. K. (2003). Case study research: Design and methods (3rd ed., Vol. 5). Newbury Park, CA: Sage. 


\section{Biographies}

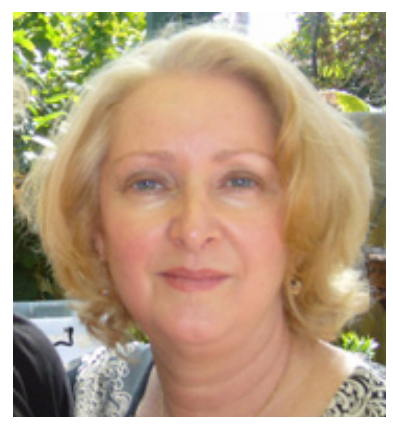

Diana Jonas-Dwyer is an Associate Professor, Medical Education and has a $\mathrm{PhD}$ in education. She works in the Education Centre at the Faculty of Medicine, Dentistry and Health Sciences at the University of Western Australia. She is passionate about technology being used in pedagogically appropriate ways to encourage student learning.

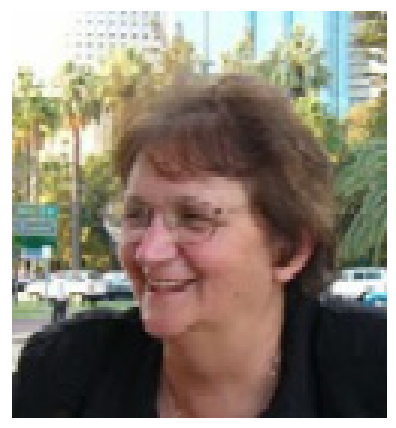

Fay Sudweeks is an Associate Professor Emerita in Information Systems at Murdoch University. She has a PhD in Communication Studies. Her research interests include the impact of technologies on learning, communication and culture. She is on the editorial board of numerous journals including the Journal of Computer-Mediated Communication, New Media and Society, Human Communication Research, and International Journal of e-Learning. She co-chairs the international and interdisciplinary conference series on Cultural Attitudes towards Technology and Communication.

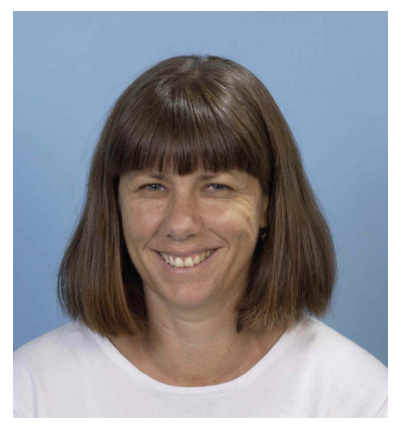

Tanya McGill is an Associate Professor in Information Technology at Murdoch University in Western Australia. She has a PhD from Murdoch University. Her major research interests include e-learning, information technology education and end user computing. Her work has appeared in various journals including Computers \& Education, Decision Support Systems, Journal of Computer Assisted Learning, Behaviour and Information Technology, European Journal of Psychology of Education.

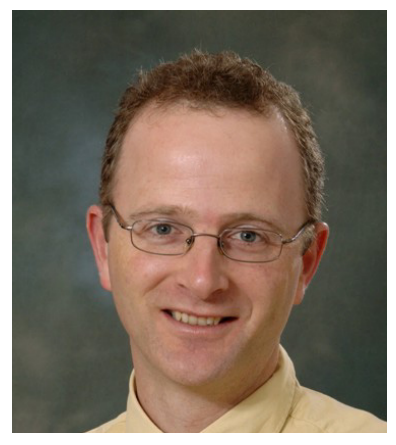

Philip Nicholls is an Associate Professor in Pathology within the Faculty of Health Sciences. Having worked in the Universities of Bristol, Cambridge and London, Phil Nicholls moved to Western Australia ten years ago to join Murdoch University. He is involved in teaching histology, general and systemic pathology and philosophy of science to students in biomedical, chiropractic and veterinary sciences, from year 1 through to graduation. In addition to teaching, his academic interests include molecular pathology and disease of species including pearl oysters, woylies, bandicoots and domestic species. 